\title{
ANALISIS BENTUK PENEDUH TERHADAP PEROLEHAN RADIASI SINAR MATAHARI PADA BANGUNAN TINGGI
}

\author{
Muhammad Sega Sufia Purnama \\ Universitas Indraprasta PGRI, Program Studi Arsitektur \\ ages125@gmail.com
}

\begin{abstract}
In high-rise building, technology has important role in giving user a comfort feeling. Unfortunately, the technology consume energy in its used. The material of façade indirectly has effect to consuming energy. In 90', massive façade is still dominant in high rise. But, in 00' glass has its tren to become a building skin. Glass material will transmit not only light but also infrared which is cause increase of temperature inside the building. Shading device is one of the solutions to block solar radiation. Simulation with Autodesk Revit Software is used in this research. Based on solar radiation data from simulation, horizontal louver shading device has better performance than others shading device.
\end{abstract}

Key Words: high-rise building, façade, shading device, solar radiation

\begin{abstract}
Abstrak. Pada bangunan tinggi, teknologi memainkan peran penting untuk memberikan kenyamanan kepada pengguna. Teknologi yang digunakan membutuhkan energi dalam pengoperasiannya. Material fasad secara tidak langsung mempengaruhi penggunaan energi pada bangunan tinggi. Bila tahun 1990an gedung bertingkat masih dominan menggunakan elemen masif sebagai kulit bangunan. Tahun 2000an kaca menjadi tren untuk material kulit bangunan. Hal ini tentu akan mempengaruhi penggunaan energi pada bangunan. Penggunaan peneduh menjadi salah satu solusi dalam menahan sinar matahari langsung. Metode yang digunakan dalam penelitian ini adalah metode kuantitatif dengan pendekatan simulasi menggunakan software Autodesk Revit. Berdasarkan data radiasi sinar matahari selama setahun baik orientasi timur maupun barat, peneduh dengan bentuk horizontal louver adalah bentuk yang paling efektif menangkal radiasi matahari.

Kata Kunci : Bangunan tinggi, fasad, peneduh, radiasi sinar matahari
\end{abstract}

\section{PENDAHULUAN}

Pada bangunan tinggi, teknologi memainkan peran penting untuk memberikan kenyamanan kepada pengguna. Teknologi yang digunakan membutuhkan energi dalam pengoperasiannya. Aspek pencahayaan dan penghawaan menjadi aspek yang paling membutuhkan energi besar dalam suatu bangunan tinggi (Yeang,1999). Dengan semakin banyaknya bangunan tinggi yang terbangun maka akan semakin banyak energi yang digunakan.

Material fasad secara tidak langsung mempengaruhi penggunaan energi pada bangunan tinggi. Bila tahun 1990an gedung bertingkat masih dominan menggunakan elemen masif sebagai kulit bangunan. Tahun 2000an kaca menjadi tren untuk material kulit bangunan. Hal ini tentu akan mempengaruhi penggunaan energi pada bangunan. Dalam hal perpindahan panas, material masif akan lebih baik untuk menghalau panas dari sinar matahari karena panas hanya berpindah secara konduksi. Untuk material kaca, masuknya radiasi sinar matahari membuat benda-benda dalam bangunan menjadi panas, tetapi panas tersebut terjebak dalam ruangan sehingga menimbulkan kerugian dari sisi energi. (Karyono,2016)

Penggunaan peneduh (Mangunwijaya, 1994) menjadi salah satu solusi dalam menahan sinar matahari langsung. Pembayangan yang terjadi pada bidang vertikal akan mengurangi efek buruk radiasi sinar matahari. Dengan adanya berbagai macam bentuk peneduh, peneliti ingin mencoba melihat efektivitasnya terhadap radiasi sinar matahari.

Dari latar belakang, didapat ada hubungan antara bentuk peneduh dan radiasi sinar matahari. Maka dari itu, rumusan masalah penelitian ini adalah bentuk peneduh seperti apa yang paling efektif dalam menanggulangi radiasi sinar matahari?

Penelitian ini dilakukan untuk mengukur performa peneduh dalam menanggulangi radiasi sinar matahari ditinjau dari bentuk peneduh. 


\section{Fasad}

Fasad berasal dari bahasa Latin, facies, bahasa Perancis, façade yang berarti bagian depan dari bangunan. Menurut Andrea Simitch dalam bukunya The Language of Architecture, fasad adalah batas antara luar dan dalam, umum dan pribadi, pelindung dari cuaca luar yang tidak bersahabat (Simitch et. al, 2014). Pengertian fasad harus dikaitkan dengan beberapa istilah yang mirip seperti building skin atau building envelope. Giovani Zamella dalam Evolutionary Optimation of Facade Design menyatakan bahwa fasad adalah bagian dari kulit bangunan dan bukan keseluruhan (Zamella et. al,2014). Hal ini juga didukung oleh Christian Schittich dalam bukunya In Detail Building Skin (Schittich, 2006).

\section{Peneduh Matahari ( Sun Shading)}

Peneduh matahari merupakan alat yang sudah sejak zaman dahulu digunakan sebagai pelindung dari panas sinar matahari (Lechner,2015). Tidak hanya fungsinya sebagai pelindung, peneduh juga digunakan sebagai elemen estetika pada bangunan. Konsepnya adalah menghalangi panas yang masuk dengan memblok sinar matahari yang datang.

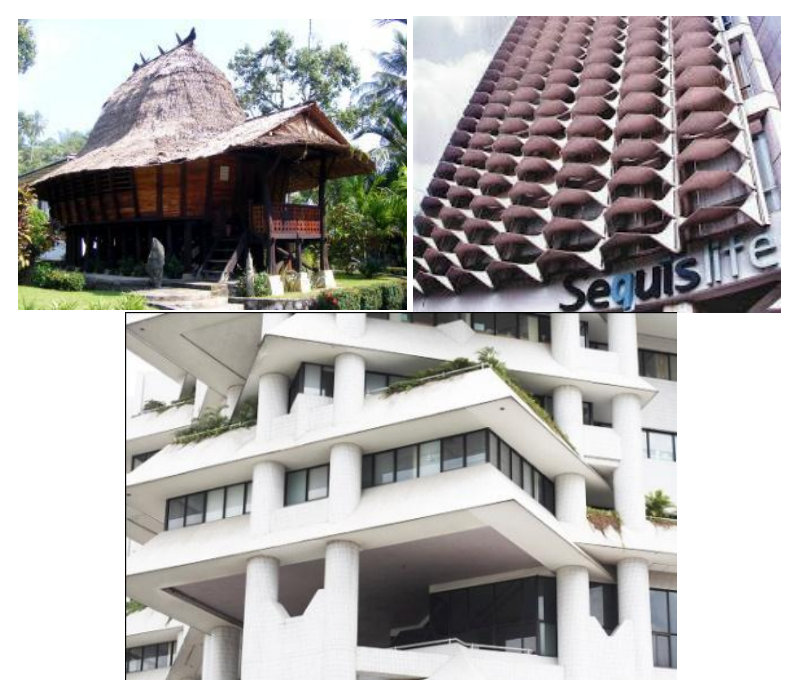

Gambar 1. Rumah Adat Nias, Sequis Center Jakarta, Wisma Dharmala

Seiring perkembangan zaman dan teknologi, peneduh matahari juga ikut mengalami perubahan dari jenis sampai bentuk. Wiley dalam Lechner mencoba untuk membuat penamaan dari setiap peneduh yang ada dan membuatnya dalam bentuk tabel seperti gambar :

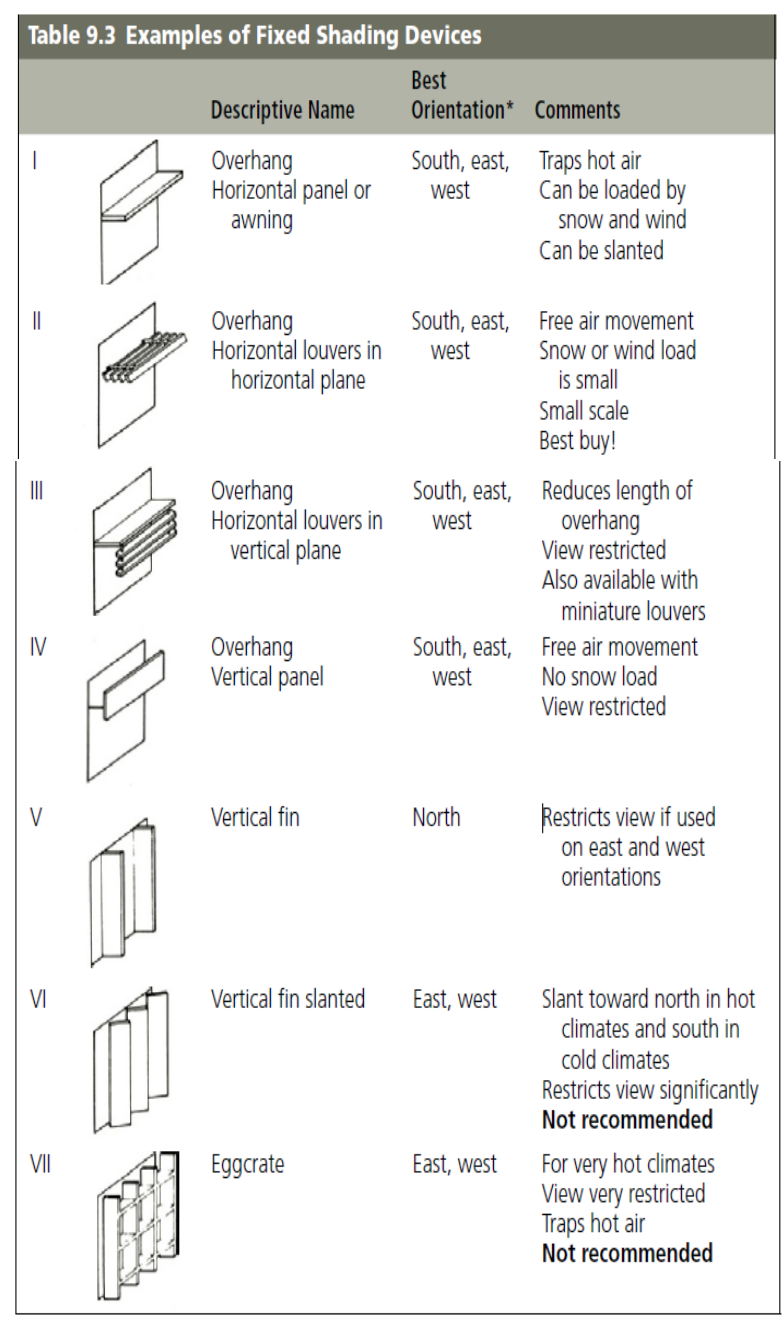

Gambar 2. Bentuk Peneduh

Dari gambar tabel tersebut terlihat penamaan yang dilakukan dan juga orientasi terbaik masing-masing peneduh. Overhang horizontal baik diletakan di bagian selatan, barat dan timur. Sirip vertikal baik diletakan di bagian utara. Tidak ada jenis peneduh yang baik untuk semua orientasi. Bentuk Eggcrate yang merupakan kombinasi horizontal dan vertikal pun mempunyai kelemahan berupa pandangan yang terbatas dan bentuk tersebut menyulitkan angin berhembus untuk memindahkan panas. Orientasi dominan dalam peletakan peneduh adalah sisi barat dan timur. Hal ini dikarenakan sisi barat dan timur merupakan sisi yang dilewati atau jalur perlintasan matahari harian. Sisi utara dan selatan tidak sepenting arah timur dan barat karena 
lintasan matahari hanya melewati sisi tersebut dalam bulan tertentu saja sehingga kurang signifikan untuk diletakan peneduh. Tetapi peletakan peneduh untuk matahari dengan sudut tinggi tetap diperlukan pada bagian tersebut.

Bangunan tinggi didominasi oleh penggunaan material transparan seperti kaca. Karena sifatnya yang meneruskan sinar matahari maka seharusnya bagian ini diberi peneduh agar tidak semua sinar matahari masuk dan memanaskan bagian dalam bangunan. Kaca saat dibuat sudah mempunyai nilai yang disebut "Koefesien Peneduh" (Shading Coefficient). Tetapi nilai ini tidak cukup untuk memberikan perlindungan terhadap sinar matahari sehingga diperlukan nilai tambah dari peneduh ekstra.

\section{Radiasi Sinar Matahari}

Panas yang mengenai bangunan berasal dari radiasi sinar matahari. Radiasi sinar matahari merupakan pancaran gelombang pendek yang menyinari bumi. Saat masuk ke dalam bangunan, gelombang pendek akan mengenai elemen dalam bangunan. Pantulan sinar dari elemen di dalam bangunan mengakibatkan panjang gelombang menjadi panjang. Panjangnya gelombang yang tidak dapat keluar dari bangunan ini yang mengakibatkan panas berlebih. Dalam bangunan dengan fasad transparan bila tidak terdapat ventilasi untuk menyalurkan panas secara konveksi, suhu akan bertambah dan mengakibatkan kenyamanan pengguna menjadi terganggu. Kejadian ini dinamakan Efek Rumah Kaca. Diperlukan pengaturan udara dalam ruang untuk mendapatkan kenyamanan yang diinginkan terutama kenyamanan termal. Terhalangnya sinar matahari yang mengenai bidang transparan akan mengurangi beban pendingin ruangan. Inilah mengapa peneduh menjadi perlu digunakan dalam bangunan tinggi.
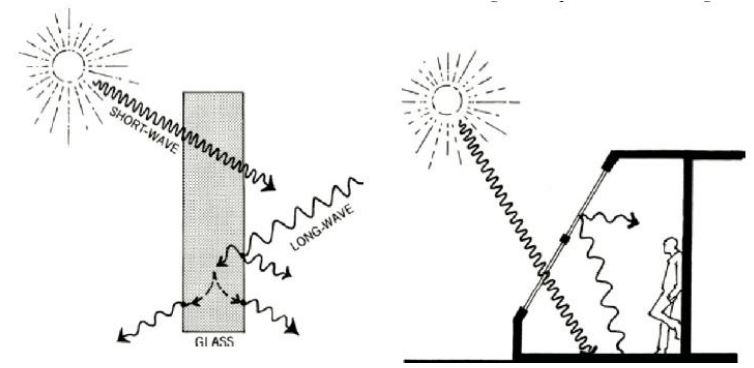

Gambar 3. Efek Rumah Kaca

\section{METODOLOGI}

Metode yang digunakan dalam penelitian ini adalah metode kuantitatif dengan pendekatan simulasi menggunakan software Autodesk Revit. Model dibuat dengan software SketchUp 2017. Untuk mewakili bidang ukur dalam software digunakan bidang berukuran $3 \times 4 \mathrm{~m}$ sebanyak dua buah. Satu sisi menghadap barat, sisi lain menghadap timur. Untuk bentuk peneduh yang digunakan adalah bentuk horizontal yaitu, overhang atau teritisan selebar $1 \mathrm{~m}$ dan louver dengan lebar $10 \mathrm{~cm}$ dan jarak antar louver sebesar $10 \mathrm{~cm}$. Bentuk vertikal berupa fins atau sirip dengan lebar $1 \mathrm{~m}$ dan jarak antar fins sebesar berkisar $1-1.5 \mathrm{~m}$. Lalu ada bentuk diagonal fins dengan kemiringan $45^{\circ}$ dan pengaturan sama dengan vertical fins. Lokasi yang digunakan untuk simulasi berada di daerah tropis, tepatnya di DKI Jakarta. Waktu pengukuran sisi timur diatur mulai jam 7 pagi sampai 11 siang. Untuk sisi barat, diatur mulai jam 1 siang sampai jam 5 sore. Data radiasi dengan satuan energi $\left(\mathrm{Wh} / \mathrm{m}^{2}\right)$ diambil dalam kurun waktu setahun dengan mengambil sampel empat tanggal penting yaitu, 21 Desember, 22 Maret, , 21 Juni dan 22 Oktober.
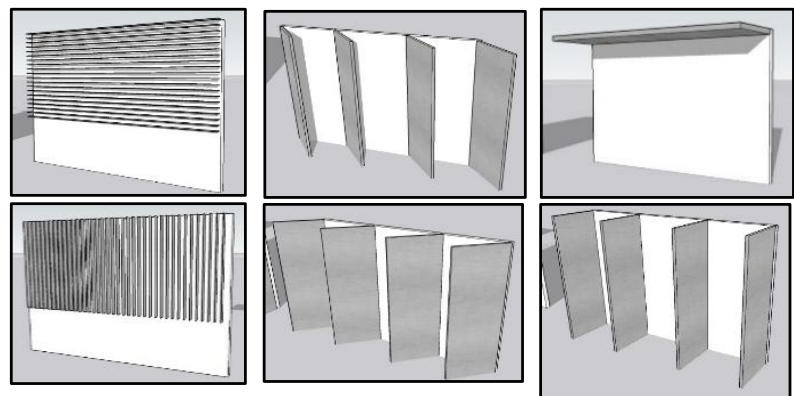

Gambar 4

Atas (kiri - kanan) : Horizontal louver, right slanted fins, overhang

Bawah (kiri - kanan) : vertikal louver, left slanted louver, vertikal fins

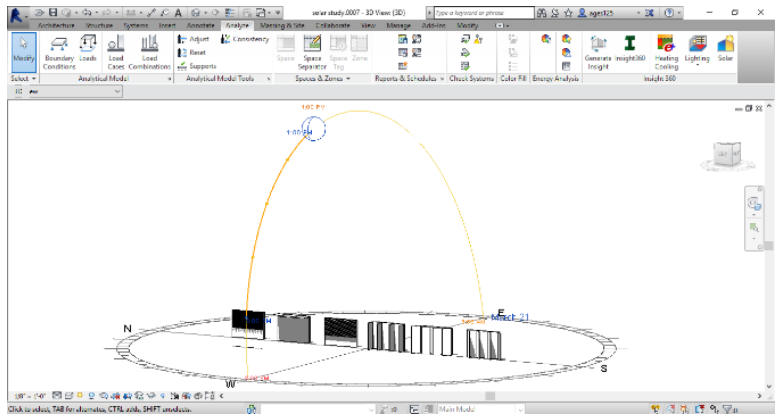

Gambar 5. Antarmuka software Autodesk Revit 


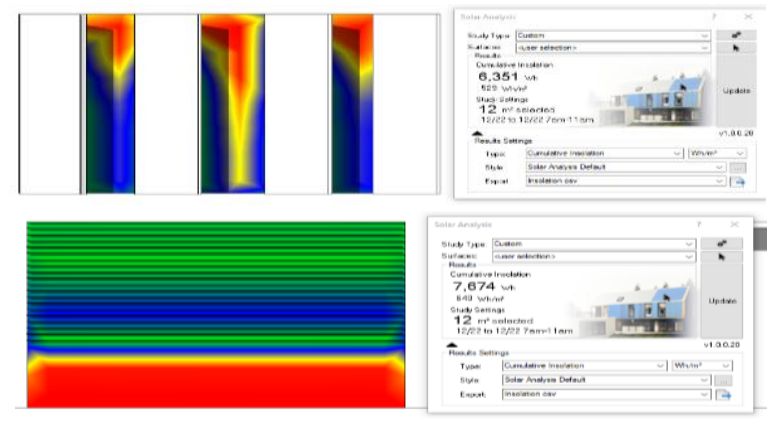

Gambar 6. Contoh hasil simulasi dengan Solar Analysis

\section{HASIL DAN PEMBAHASAN}

Tabel 1. Hasil Simulasi Radiasi Matahari dengan Software Revit

\begin{tabular}{|l|c|c|c|c|c|}
\hline \multirow{2}{*}{ Peneduh } & \multicolumn{5}{|c|}{ Nilai radiasi (pukul 7 - 11) pada bidang menghadap } \\
\cline { 2 - 6 } & $\begin{array}{c}\mathbf{2 1} \\
\text { Maret }\end{array}$ & $\begin{array}{c}\mathbf{2 1} \\
\text { Juni }\end{array}$ & $\begin{array}{c}\mathbf{2 1} \\
\text { Oktober }\end{array}$ & $\begin{array}{c}\mathbf{2 1} \\
\text { Desember }\end{array}$ & $\begin{array}{c}\text { Rata- } \\
\text { rata }\end{array}$ \\
\hline $\begin{array}{l}\text { Horizontal } \\
\text { Louver }\end{array}$ & 1053 & 878 & 828 & 640 & 849.75 \\
\hline Overhang & 1390 & 1211 & 1077 & 882 & 1140 \\
\hline $\begin{array}{l}\text { Vertikal } \\
\text { louver }\end{array}$ & 1880 & 975 & 1426 & 892 & 1293.25 \\
\hline Fins & 1921 & 988 & 1424 & 953 & 1321.5 \\
\hline $\begin{array}{l}\text { Fins } 45^{0} \\
\text { (left) }\end{array}$ & 1009 & 482 & 1054 & 1038 & 895.75 \\
\hline $\begin{array}{l}\text { Fins } 45^{0} \\
\text { (right) }\end{array}$ & 1296 & 1356 & 799 & 529 & 995 \\
\hline
\end{tabular}

\begin{tabular}{|l|c|c|c|c|c|}
\hline \multirow{2}{*}{ Peneduh } & \multicolumn{5}{|c|}{ Nilai radiasi (pukul 13 - 17) pada bidang menghadap } \\
& \multicolumn{7}{|c|}{$\begin{array}{c}\mathbf{2 1} \\
\text { barat }\left(\mathbf{W h} / \mathbf{m}^{2}\right)\end{array}$} & $\begin{array}{c}\mathbf{2 1} \\
\text { Juni }\end{array}$ & $\begin{array}{c}\mathbf{2 1} \\
\text { Oktober }\end{array}$ & $\begin{array}{c}\mathbf{2 1} \\
\text { Desember }\end{array}$ & $\begin{array}{c}\text { Rata- } \\
\text { rata }\end{array}$ \\
\cline { 2 - 6 } $\begin{array}{l}\text { Horizontal } \\
\text { Louver }\end{array}$ & 1089 & 846 & 1031 & 919 & 971.25 \\
\hline Overhang & 1470 & 1192 & 1416 & 1277 & 1338.75 \\
\hline $\begin{array}{l}\text { Vertikal } \\
\text { louver }\end{array}$ & 2003 & 919 & 1697 & 1269 & 1472 \\
\hline Fins & 1990 & 947 & 1805 & 1323 & 1516.25 \\
\hline $\begin{array}{l}\text { Fins 45 } \\
\text { (left) }\end{array}$ & 1496 & 1382 & 1010 & 829 & 1179.25 \\
\hline $\begin{array}{l}\text { Fins 45 } \\
\text { (right) }\end{array}$ & 1162 & 536 & 1443 & 1457 & 1149.5 \\
\hline
\end{tabular}

Hasil simulasi pada orientasi timur. Horizontal louver, overhang, vertical louver fins dan fins $45^{\circ}$ (right) menunjukan performa terbaiknya pada tanggal 21 Desember. Fins $45^{\circ}(l e f t)$ menunjukan performa terbaiknya justru pada tanggal 21 Juni. Hal ini diakibatkan oleh kemiringan lintasan matahari tegak lurus dengan kemiringan fins sehingga sinar matahari mampu ditahan dengan baik oleh fins. Hal ini berbanding terbalik dengan fins $45^{\circ}($ right). Nilai radiasi justru besar di tanggal 21 Juni dikarenakan sejajarnya sinar matahari dengan kemiringan bilah. Nilai radiasi yang besar juga didapatkan oleh fins dan vertical louver pada tanggal 21 Maret dan 21 Oktober. Faktor yang mempengaruhi nilai tersebut adalah lintasan matahari yang tegak lurus dengan permukaan bumi sehingga sudut datang yang tinggi membuat nilai radiasi menjadi besar. Dari nilai rata-rata performa peneduh didapatkan nilai radiasi terbesar dimiliki oleh fins dan nilai radiasi terkecil dimiliki oleh horizontal louver.

Hasil simulasi pada orientasi barat. Horizontal louver, overhang, vertikal louver dan fins menunjukan performa lebih baik saat tanggal 21 Juni dan 21 Desember. Faktor yang mempengaruhi hal ini adalah kemiringan lintasan matahari pada titik terjauhnya sehingga sudut datang yang tidak begitu besar membuat nilai radiasi menjadi lebih kecil. Pada tanggal 21 Maret dan 21 Oktober nilai radiasi menjadi besar karena lintasan matahari yang hampir tegak lurus sehingga radiasi menjadi lebih besar. Fins $45^{\circ}($ left $)$ mempunyai nilai radiasi terkecil di tanggal 21 Juni dan fins $45^{\circ}$ (right) mempunyai nilai terkecil di tanggal 21 Desember. Dari rata-rata nilai radiasi, peneduh horizontal louver memiliki nilai terkecil dibandingkan peneduh lainnya.

Dari simulasi pada bidang, didapatkan nilai radiasi pada orientasi barat lebih besar dari orientasi timur. Faktor yang mempengaruhi ini adalah sudut datang sinar matahari terhadap bidang vertikal, sinar matahari yang berdifusi dari langit dan pantulan sinar matahari dari permukaan bumi.

\section{PENUTUP}

\section{Simpulan}

Simpulan yang dapat diambil dari simulasi peneduh adalah berdasarkan data radiasi sinar matahari selama setahun baik orientasi timur maupun barat, peneduh dengan bentuk horizontal louver adalah bentuk yang paling efektif menangkal radiasi matahari. Hal ini terlihat dari rendahnya nilai radiasi yang didapatkan. Kerapatan dan lebar kisi tidak mempengaruhi perolehan radiasi sinar matahari. Kemiringan yang dimiliki oleh fins bekerja dengan baik saat kemiringan sinar matahari tegak lurus dengan kemiringan bilahnya. 


\section{DAFTAR PUSTAKA}

Karyono, Tri Harso. (2016). Arsitektur Tropis : Bentuk, Teknologi, Kenyaaman, dan Penggunaan Energi. Jakarta. Erlangga

Lechner, N.. (2015). Heating, Cooling, Lightning. New Jersey. Wiley \& Sons

Mangunwijaya, Y. B. (1994). Fisika Bangunan. Jakarta. Djambatan

Schittic, C.. (2006). In Detail - Building Skins. Basel. Birkhauser

Simitch, A. et.al.. (2014). The Language Of Architecture. Baverly. Rockport

Yeang, K.. (2012). Green Skyscrape. Munich \& New York. Prestel

Zamella, G. \& Andrea Faraguna. (2014). Evolutionary Optimisation of Facade Design. London. Springer 